\title{
"Arabic is the language of the Muslims - that's how it was supposed to be": exploring language and religious identity through reflective accounts from young British-born South Asians
}

\author{
Rusi Jaspa ${ }^{a *}$ and Adrian Coyle ${ }^{\mathrm{b}}$ \\ ${ }^{a}$ Department of Psychology, University of London, Royal Holloway, Egham Hill, \\ Egham, TW20 OEX United Kingdom; ${ }^{b}$ Department of Psychology, Faculty of Arts and \\ Human Sciences, University of Surrey, Guildford, GU2 7 XH United Kingdom
}

(Received 16 April 2009; final version received 18 June 2009)

\begin{abstract}
This study explores how a group of young British-born South Asians understood and defined their religious and linguistic identities, focusing upon the role played by heritage languages and liturgical languages and by religious socialisation. Twelve British-born South Asians were interviewed using a semi-structured interview schedule. Interview transcripts were subjected to interpretative phenomenological analysis. Four superordinate themes are reported. These addressed participants' meaning-making regarding "the sanctification of language" and the consequential suitability of "the liturgical language as a symbol of religious community"; the themes of "ethnic pride versus religious identity" and "linguistic Otherness and religious alienation" concerned potential ethno-linguistic barriers to a positive religious identity. Findings are interpreted in terms of concepts drawn from relevant identity theories and tentative recommendations are offered concerning the facilitation of positive religious and ethnic identities.
\end{abstract}

Keywords: identity; religion; culture; language; South Asians; interpretative phenomenological analysis; qualitative

\section{Introduction}

In recent years, the macro-sociolinguistic tradition has witnessed the emergence of a new sub-discipline, namely the sociology of language and religion, which considers the theoretical links between language, religion and sociology (Omoniyi \& Fishman, 2006). The birth of this sub-discipline may be attributed to the partial and inadequate foci of individual disciplinary approaches: linguistics has been largely preoccupied with the analysis of linguistic structure whereas social scientists have generally underestimated the value of linguistic, and particularly sociolinguistic, theory in language-related studies (Hymes, 1972). For many years, scholars have highlighted the limitations inherent in addressing the interface between language and social life from the perspective of a single discipline (e.g. Fishman, 1991). Here it is argued that a social psychological approach may be a particularly fruitful point of departure given that this discipline has a long tradition

*Corresponding author. Email: rusi.jaspal@gmail.com

ISSN 1367-4676 print/ISSN 1469-9737 online

(C) 2010 Taylor \& Francis

DOI: $10.1080 / 13674670903127205$

http://www.informaworld.com 
of studying both the micro and the macro levels of identity, including categorisation and identity processes as well as intergroup processes (Verkuyten, 2005). Furthermore, many writings demonstrate the potential social and psychological repercussions of bilingualism (e.g. Wei, 2000) and of religious affiliation (e.g. Hunsberger \& Jackson, 2005; Miller \& Kelley, 2005; Pargament, 1997). Thus, it may be beneficial to anchor some of the issues being discussed in the sociology of language and religion within social psychological theories of identity in order to explore this multi-faceted phenomenon.

This article examines the role of language in the construction of religious identity, specifically among a group of second generation Asians (SGAs) in the east midlands of England. The decision to focus upon this particular population arose from the fact that contemporary thought on language and religion has largely been anglocentric (e.g. McGrath, 2002), despite findings that in the West "the majority of people under the age of sixty have become extremely reticent about proclaiming a Christian identity," with young people throughout Europe displaying "similar antipathy to traditional religious identities" (Joseph, 2006, p. 176). On the other hand, contemporary research on language and the major religions of South Asia has generally focused upon the specific context of the Indian subcontinent (e.g. Pandharipande, 2001, 2006), and not the South Asian diaspora. Thus, there is a need for research focusing upon British Asians, as their experiences of language and religion are likely to differ from those of "indigenous" South Asians. For instance, it is noteworthy that most British Asians lay claim to a religious identity and that, for Pakistanis in particular, this identity tends to take precedence over all others (Jacobson, 1997). Furthermore, SGAs are in the particularly intricate position of having to manage their "linguistic repertoires" which in many cases feature (1) English, (2) their heritage language (HL) which represents the language associated with their ethnic culture and (3) their liturgical language (LL) which is the language reserved for religious purposes (primarily worship and religious instruction/training).

\section{Multiple identities and multilingualism}

The major South Asian (ethnic) groups in the east midlands of England include Punjabis (who usually follow the Sikh, Hindu or Muslim religions), Gujaratis (a majority of whom are Hindus) and Mirpuris (who are predominantly Muslims). The respective HLs of the aforementioned groups are Punjabi/Urdu, Hindi, Gujarati and Mirpuri, all of which are mutually intelligible with only slight grammatical and lexical differences (Singh, Dasgupta, \& Lele, 1995). These languages continue to be used among SGAs (Harris, 2006) perhaps because the South Asian communities in Britain tend to have dense (intragroup) social networks and because regular visits to their respective countries of origin are common (Bagguley \& Hussain, 2003). A possible psychosocial explanation for the maintenance of South Asian HLs is that language plays an extremely important role in determining ethnicity (Rosowsky, 2008). Yet religion also has its linguistic demands. As Rosowsky (2006) notes, it is impossible for Muslims to pray without reading the opening chapter of the Qur'an, which is in Arabic. Similarly, in the Gurdwara (the Sikh place of worship), the Guru Granth Sahib (the Sikh holy book) is read aloud in its original language, Gurmukhi (Singh, 2005). At a national level though, SGAs are under considerable pressure to attain high literacy skills in English in order to fully integrate into British society (Blunkett, 2002) and for vertical social mobility (Samuels, 1995).

Thus, it would appear that each of these three dimensions of SGA identity (national, ethnic and religious) ought to be considered in its own right since, in many cases, each 
collective identity corresponds to a distinct linguistic identity. One might assume that SGAs manage their complex linguistic repertoires in accordance with their ethnic, national and religious identities and that the identities are compartmentalised (Roccas \& Brewer, 2002). This study seeks to investigate this assumption with a particular focus upon the construction of religious identity. Moreover, the role of language and religious identity is considered within the wider context of individuals' complex linguistic repertoires consisting of various languages. The aim is to explore individuals' accounts of their psychological management of their complex linguistic repertoires as well as the implications of this for their religious identities.

\section{Religious identity and prescribed norms}

When thinking about the nature and expression of religious identity, it is important to distinguish between religious beliefs and institutional practices. For example, there is evidence to suggest that Judaism can be expressed in cultural rather than spiritual terms (Gitelman, Kosmin, \& Kovacs, 2003; Webber, 1997). Similarly, Enneli, Modood, and Bradley (2005) found that many of their Turkish participants regarded being Muslim as a cultural rather than religious identity. Consequently, religious identity might refer to a system of religious beliefs and to religious/spiritual experience for some SGAs whereas for others it could be akin to a form of cultural identity. Such a fluid conceptualisation of religion is of paramount importance to this study, since the objective is to understand the role of language in SGAs' religious identities, however religious identity is defined by them.

Members of a religious group are likely to share similar social representations of the norms and practices associated with their religious identities; this may include use of the LL. Beit-Hallahmi and Argyle (1997, p. 25) state that the psychological mechanisms associated with religious practice are conformity and "the replicative transmission of behavioural repertoires." This might explain why some aspects of religion, such as historic LLs, are often safeguarded and preserved as essential components of religious practice. It could perhaps be argued that individuals' "learning" of their religious identities is a process analogous to the learning of one's native language. Indeed, language maintenance is largely contingent upon parents' desire to transmit the language to their children (Gupta \& Yeok, 1995). Thus, one might assume that religion is an ascribed identity and that, in a similar way, the LL in which the religious identity is communicated to the individual is also the prescribed code. Rosowsky (2006, p. 313) notes that in order for young Muslims to study Koranic Arabic, thereby enabling them to participate in religious activities, "considerable investment in terms of time and money has to be expended." Therefore, learning the LL is perhaps comparable to a "rite of passage," a standardised pattern of social behaviour endorsed by the individual's parents, which allows initiation into the religious community and thus access to the religion. Consequently, many young SGA may come to privilege their religio-linguistic identities over their ethno-linguistic identities (Rosowsky, 2008).

One might wonder why individuals attach such importance to the LL and why religious groups have come to prioritise use of the LL in religious settings. Much sociological work highlights the role of language as a marker of collective identity; it becomes a symbol of group identification and distinctiveness (Baker, 2001; Brass, 2005). Speakers come to feel connected through their common use of the language (Wolf, 2001) and it could therefore be hypothesised that language can function as a salient self-aspect which forms the basis 
of a cohesive collective identity (Simon, 2004). Thus, it is reasonable to assume that, although language is unlikely to constitute the self-aspect which gives rise to collective religious identity, it may be employed as a tool to strengthen the sense of community and "oneness." This appears to connect with Ward's (2000) work, which convincingly demonstrates the importance of community and group identity in the world's major religions, despite the widespread assertion that religion primarily concerns the individual and their relationship with God.

\section{"Pretended bilingualism”}

Many religions attach much importance to the maintenance of their respective LLs. Rosowsky (2007) notes that British Muslim children attending Islamic schools, many of whom are Mirpuri-speaking, are expected to memorise prodigious amounts of text in Classical Arabic as part of their religious training. The meaning of the verses recited is seldom understood but SGAs' religious socialisation ensures that they believe that "these words are good and directed to God" (p. 314).

Here one might consider Dzialtuvaite's (2006) notion of "pretended bilingualism," which refers to the dual linguistic situation of using the LL for symbolic purposes and the community's dominant language to facilitate understanding. This is especially relevant given that use of the LL can appear to be redundant at a time when there is a lengthy tradition of English language commentary on these religions, which arguably enables monolingual SGAs access to their religions. However, under close scrutiny, this assertion is problematic. For example, the authoritative translation of the Islamic Koran by the eminent Western scholar of Islam, Mohammed Marmaduke Pickthall, which is entitled The Meaning of the Glorious Koran (Pickthall, 1997, p. 7), unambiguously states in the translator's foreword that "the Koran cannot be translated. That is the belief of the oldfashioned Sheykhs and the view of the present writer [... It [a translation] can never take the place of the Koran in Arabic, nor is it meant to do so." The hegemony of Arabic as the language of Islam is emphasised through the author's rejection of English as a means of accurately reflecting the essence of the Koran. It is noteworthy that it is the media and literature such as this which play a vital role in the authentication (or rejection) of particular languages as symbols of religious identities (Pandharipande, 2006).

Since English is the dominant language of most British SGA Muslims (Harris, 2006), the individuals who lack competence in the LL may believe that their access to Islam is somehow "tainted" due to their having access to the translated meaning of the Koran rather than to the Koran itself. Furthermore, it is questionable whether Islam is truly able to reach out to young multilingual Muslims in the way in which it was originally intended. Despite calls for the use of English in mosques, it has been observed that language shift in religious contexts can be viewed as a threat to the "true" expression of ethno-religious identity (Fishman, 1996), which may explain the lack of "linguistic pragmatism." Although the role of Koranic literacy in the lives of UK Muslims is addressed in the literature (Rosowsky, 2006, 2007, 2008), there have been no serious studies of the social psychological implications of many SGAs' lack of competence in their LL for their religious identities.

This research explores how young British SGAs themselves understand and define their religious and linguistic identities. Through the detailed analysis of participants' reflective accounts, the study investigates the role of English and individuals' LLs and HLs in the construction of religious identity, with a particular focus upon religious socialisation 
during childhood. The social and psychological issues associated with this are of particular interest to the study. Furthermore, participants' evaluative attitudes towards languages associated with their religions are also investigated with particular sensitivity to contextual factors.

\section{Method \\ Participants}

In light of sampling guidelines associated with this study's analytic approach (Smith \& Osborn, 2008), attempts were made to recruit a relatively homogeneous sample of participants from the South Asian community in a city in the east midlands of England. Twelve participants were recruited, who, in order to be eligible for the study, were required to be British-born South Asians, to identify as Muslim, Sikh or Hindu and to be aged between 18 and 24. The study focused solely upon the experiences of self-identified Muslims, Sikhs and Hindus of Indian and Pakistani heritage as these are the most important South Asian groups in the city. Furthermore, it was assumed that individuals born in the Indian subcontinent would have had different linguistic, religious and cultural experiences from British-born individuals and thus a differential relationship to their linguistic repertoires, which might have undermined the homogeneity of the sample.

A snowball sampling strategy was employed, with the initial participants recruited through the first author's social networks. Of the 12 participants, seven were males and five females, with a mean age of 21.6 years $(S D: 1.3)$. Six participants were university students, one had a Masters degree, and the remaining five had GCSE/A-levels. Nine of the participants were of Punjabi origin (i.e. both parents were from Punjab), two were of Gujarati origin and one was mixed race (one parent was from Punjab and the other was White British).

\section{Interview schedule}

Participants were interviewed using a semi-structured interview schedule consisting of 11 exploratory, open-ended questions. The schedule began with questions regarding self-description and identity, followed by questions on religious and ethnic socialisation, the construction of religious and ethnic identities, the roles of the HL and LL in their lives, the management of any difficulties arising from their religious, ethnic and national identities, and questions eliciting reflections upon linguistic experiences. Explanatory probes were used where necessary.

Five participants were interviewed in their homes, three in the interviewer's home and the remaining four at a youth centre. Interviews lasted between 60 and 90 minutes. They were digitally recorded and transcribed verbatim.

\section{Analytic approach}

The data were analysed using IPA (Smith, 1996; Smith \& Osborn, 2008), which is a qualitative analytic technique that aims to capture participants' attempts to make sense of relevant aspects of their personal and social worlds. IPA conceptualises the participant as a "cognitive, linguistic, affective and physical being" (Smith \& Osborn, 2008, p. 54) and assumes a relationship between verbal reports and the cognitions and emotions with which they are concerned. Since IPA focuses upon the meanings that particular lived experiences 
hold for the individual, it was anticipated that this analytic strategy would shed light upon the subjective perceptual processes associated with participants' attempts to make sense of their religious and ethnic identities and the roles played by language in these identities. Moreover, IPA's idiographic mode of enquiry (Smith, Harré, \& van Langenhove 1995) encouraged an in-depth exploration of each individual's account of their experiences, which was useful, given that the literature implicitly highlights the need for an exploratory approach.

Turning to the analytic procedures, first the transcripts were read repeatedly in order to become as intimate as possible with the accounts. During each reading, preliminary impressions and interpretations were noted in the left margin. Subsequently, the right margin was used to note emerging theme titles which captured the essential qualities of the accounts. This procedure was repeated with every interview transcript, each of which gave rise to five or six main themes. The main themes of each transcript were themselves organised into a final set of superordinate themes, although some of the original main themes, which did not directly address the research questions, were discarded. The superordinate themes representing the 12 accounts were then ordered into a logical and coherent narrative structure.

The analysis presented here features a degree of methodological innovation in order to create a rich and detailed analysis of the phenomena under investigation. IPA has been subject to criticism from a social constructionist perspective on account of its assumptions about the nature of language and its inattention to the constitutive role of language for experience (Willig, 2007). While this study is located within a critical realist rather than a social constructionist epistemology, the analysis considers the use of discursive categories and the functions performed by participants' accounts as part of a pluralist interpretative endeavour alongside more phenomenological analyses. It is hoped that the IPA repertoire might be advanced through considering the outcomes of such methodological "play."

In the quotations from participants that are presented in the next section, three dots within square brackets indicate where material has been excised; other material within square brackets is clarificatory; text in italics indicates words that were stressed by participants; and material in round brackets indicates broad para-linguistic features.

\section{Analysis}

This section reports some of the most important themes which elucidate participants' cognitions about and experiences of, language within the context of religious identity and practice. It considers participants' individual meaning-making regarding "the sanctification of language" and the consequential suitability of "the liturgical language as a symbol of religious community." The themes "ethnic pride versus religious identity" and "linguistic Otherness and religious alienation" address potential ethno-linguistic barriers to a positive religious identity.

\section{The sanctification of language}

A central concern in this research was to explore how SGAs think about their LL within the context of their own religious identities. Participants frequently referred to the perceived holiness of their LL, which was commonly attributed to its use in the history 
of the religion. For example, Zak's account highlighted the pivotal role of saintly religious figures in the sanctification of Arabic:

Arabic is holy [...] It's the language the Prophet Mohammed used to speak in so it's holy for Muslims.

Following Pargament and Mahoney's (2005, p. 183) conceptualisation of sanctification as "a process through which aspects of life are perceived as having divine character and significance," it is argued that language becomes sanctified. Zak perceives an inherent holiness in the Arabic language, which he attributes to the Prophet's own use of the language during his lifetime. Indeed, Muslims view Mohammed as the final and the greatest prophet of Islam and as a messenger of Allah (Esposito, 2002). Thus the Prophet's "hadiths," that is, his traditions and sayings, are revered and interpreted as an important source of religious and moral law (Robson, 1971). It might be argued that, through this process of sanctification, Arabic is conceptualised as the most desirable linguistic code for Muslims solely because the Prophet used the language himself. Due to the Prophet's own use of Arabic, its use perhaps comes to be viewed as an indirect prophetic ruling or "hadith." As Mariam observed:

Arabic is the language of the Muslims - that's how it was supposed to be.

While Zak appeared to prioritise the language which the Prophet had personally used, some participants made overt reference to the language in which Holy Scripture had been composed. Veer, a Sikh participant, expressed his view of Gurmukhi:

It [modern Punjabi] is not like the language of the Guru Granth Sahib Ji. I mean, that language is what the Gurus used and its meaning is religious [...] Their language was beautiful when they spoke it but like now you've got slang in Punjabi.

An evaluative comparison is made between modern Punjabi, a language which Veer initially described as his "mother tongue," and "the language of the Guru Granth Sahib." Although much of the existing literature depicts the "mother tongue" as a vital aspect of identity, "an aspect of the soul, if not the soul itself made manifest" (Fishman, 1972, p. 48), here this language does not appear to take precedence over that of Holy Scripture. Rather, it is viewed as having deviated from the "beautiful" LL. Veer's account appears to assume a relationship between the LL and that spoken by the Sikh Gurus, which in turns sanctifies the language of holy scripture: "its meaning is religious." Since in Sikhism the holy book is considered not only the final Guru but also the ultimate embodiment of the preceding 10 human Gurus (Singh, 2005), one might interpret Veer's conceptualisation of the Guru Granth Sahib in anthropomorphic terms. While some Muslim participants made direct reference to the language of the Prophet Mohammed, a human being, several Sikh participants, like Veer, referred to a holy object which was no less than human for some. For example, Baljit said:

In Punjabi school they'd tell us er like stories and in one she was like 'You should never put a bookmark in the Guru Granth Sahib' and then she told us that Guru Nanak Dev Ji said once in his life that he couldn't er get to sleep because he felt something in his eye all night.

Baljit's account echoes writings on Sikhism. It has been observed that the holy book is attended with an air of royalty; it is placed on a throne and fanned while devotees bow down before it upon entry into and departure from the Sikh temple (Fowler, 1997). Furthermore, participants' unanimous use of the respectful suffix "ji" - commonly used to address elders and those in high positions - indicates their immense respect for the holy book. 
Perhaps individuals construct these languages as holy due to their association with holy beings or with holy objects with supposed human characteristics. However, one Shiite Muslim participant's account identified an additional factor which could lead to the sanctification of language. Yush described the annual Day of Ashura which is commemorated among Shiites as a day of mourning for the martyrdom of Hussein Ibn Ali, the grandson of the Prophet Mohammed. On this day, mourners attend the mosque and listen to sermons recounting the fateful Battle of Kerbala and thereby relive the pain and sorrow allegedly endured by Hussein and his family (Shankar, 2003; Waugh, 1977). At Yush's mosque the sermons are delivered in Urdu, commonly conceptualised by participants as their HL. Yush reflected upon the significance of this:

Yush: It's the words, the sounds, the sweetness of Urdu that makes us weep and cry out

'Hussein' and that touches me [...] It [Urdu] is how I've heard the Ulama [Muslim cleric] talk

of this sad thing and it is the one that makes me feel the Prophet's family here with me.

Interviewer: Would it work in English?

Yush: No, no, I don't think so. I don't know. It'd be just like a history book. Like, I never cry

when I read er read like about the World Wars.

Yush's account highlights that, within the context of Islam, the process of sanctification is by no means confined to Arabic - the language of the Prophet and of the Koran. For him, these sermons could only possibly be appreciated in Urdu and this argument is constructed as credible through direct reference to the phonology of the language ("the sounds, the sweetness of Urdu") and "the words" which "touch" the listener. In addition to the perceived inherent eloquence of Urdu, Yush also observes that habit and custom may play a significant role in the sanctification of language; he has only heard this religious account in one language and is therefore unable to entertain the idea of receiving it in any other:

It'd [English] just feel weird. It's always been Urdu since I can remember.

For Yush, English would render these unique religious accounts indistinguishable from historical accounts of the World Wars which clearly do not evoke the same emotions for him as the accounts of Hussein's martyrdom. Consequently, Urdu, alongside Arabic, is also considered by Yush to be a LL within a specific religious context. The LL was also discussed within the context of religious community.

\section{The liturgical language as a symbol of religious community}

Although a majority of participants emphasised their personal relationships with God and their religions, reiterating the importance of personal belief and practice, an unambiguous sense of community was also expressed in many accounts. The LL was often constructed as a paramount symbol of this religious community.

\section{Utopian vision of a homogeneous liturgical language}

Possibly in order for it to represent a cohesive religious community, the language itself was often constructed as being cohesive and uniform. This was particularly interesting in light of the strong emphasis upon inherent variation in language in the sociolinguistic literature (Carbonero, 2003; Hudson, 2001). Sameer suggested that:

We [Muslims] all speak the same language [... ] You can go anywhere and Muslims in Morocco, Yemen, Palestine speak Arabic so it's just one language and there's unity with Muslims. 
His thoughts were shared by others:

Interviewer: Why [do you study] Arabic though?

Saba: Because it's a Muslim language. Muslims should know it to communicate.

These participants are not referring solely to Arabs, who indeed would identify Arabic as their everyday language, but to Muslims in general. Sameer, a British Pakistani, appeared to disregard any sense of national identity and with it any sense of national language. Clearly, the only plausible linguistic code capable of binding Muslims across the world is considered to be Arabic. Despite this, he and Saba appeared to blur the conceptual boundaries between language as an instrument of communication, in which case Arabic could not possibly be viewed as a homogeneous community "binder," and its role as a marker of religious identity. The utopian vision of Arabic as a language spoken by all Muslims, which would allow individuals to communicate "anywhere", appeared to signal a nostalgic desire for linguistic unity among Muslims based upon the LL.

While Muslim participants tended to emphasise the value of Arabic, some Hindu participants alluded to the importance of Sanskrit as a symbol of community cohesion. Pritika, for instance, reflected upon the use of Sanskrit in the Hindu temple:

They [worshippers] all just seem to understand it all [Sanskrit] and go along with it and like there is a lot of similarity er sameness in them [...] Then the priest speaks Hindi and you can't even tell who is Gujarati and who is Punjabi because they are all Hindu [...] They all speak Hindi and they understand Sanskrit. I don't.

Pritika's account of the use of LL in the temple was representative of the accounts of many other participants who expressed their inability to understand Sanskrit and their difficulties in understanding Hindi. For example, Kiren said:

I can only really understand my mum and dad talking Hindi [...] They speak it like slow and in their own way.

Participants believed that the widespread ability to understand Sanskrit among the first generation served to bind the group in a cohesive manner whereby a sense of "sameness" and "similarity" could be perceived from outside. Unable to understand the sermons herself, Pritika appeared to position herself as "Other" to this cohesive community:

I just don't feel a part of it really.

Furthermore, Pritika's account exhibits her inability to discriminate between the different ethnic groups present in the temple due to their linguistic communality; the salient collective identity in this context is constructed as the devotees' religious identity as Hindus. It could be argued that in the psychological worlds of some participants, it is this common LL which underlies a cohesive and unified religious community. Thus, perhaps it is the social context of the Hindu temple which contributes to participants' shared social representations of Sanskrit and Hindi as markers of (collective) religious identity. However, there was some ambivalence vis- $a$-vis the perceived functions of a common language. The following section explores alternative functions of a common language in contexts in which religion does not constitute the salient collective identity.

\section{Reconciliation: transcending religious boundaries}

Individuals were encouraged to reflect upon personal instances of intergroup contact, such as contact with South Asians with different religious beliefs from their own. 
Participants widely reported having used a more "neutral" form of their HL, devoid of overt religious connotations, to address these religious outgroups:

Like instead of 'Asalaam alaikum', which I'd never say, we just say 'Hello ji' (Baljit)

Muslims usually use the greeting "Asalaam alaikum" whereas Sikhs generally greet each other with "Sat Sri Akaal" (Kalra, Purewal, \& Ward, 2001). However, Baljit does not opt for the greeting associated with his religion (Sikhism), which perhaps implies his acknowledgement of difference between himself and his interlocutor, and similarly, he refuses to use the Islamic greeting. Use of the neutral English term "hello" with respectful suffix "ji" perhaps constitutes a compromise: Baljit is courteous yet maintains his sense of religious distinctiveness. Given his curt statement that he would "never" use the Muslim greeting, perhaps it could be argued that for him to use this greeting could imperil this sense of religious distinctiveness (Breakwell, 1986):

They [Muslims] are never willing to meet you half-way. Well, neither am I - I'm a Sikh and we have our customs too. (Baljit)

For some participants who offered reflective accounts of inter-religious communication, use of their HL in inter-religious contexts was seen as deconstructing inherited "myths" of difference and thereby reconciling allegedly incompatible religious groups. Manjinder, a Sikh woman, who had worked as a cashier recounted her experiences:

This Muslim woman came into the pharmacy and she was waiting to be served by me [...] I talked my [variety of] Punjabi and she spoke hers and we understood each other fine and she seemed genuinely grateful that I spoke to her in her language, our language. I realised we are just the same after the religion barrier. We speak the same language practically [...] It [stories of difference] felt like a myth.

Manjinder's account indicates that, while the LL can delineate religious communities, use of the HL (or a language conceptualised by individuals as HL) can have the opposite effect. It was successfully employed as an instrument of inter-religious communication: "we understood each other." Moreover, the language served to emphasise the similarities between Manjinder and an individual whom Manjinder would have viewed primarily in religious, rather than ethnic, terms. Two distinct varieties of Punjabi which had previously been viewed as markers of religious identity (Pandharipande, 2006) were now conceptualised as one unitary language: "our language." Furthermore, overt reference was made to the deconstruction of "the religious barrier" which, from Manjinder's perspective, now constituted a myth. Crucially, it appears to be the realisation that she and her Muslim customer "speak the same language practically" which encourages her to view the relationship between Muslims and Sikhs in ethnic terms, emphasising similarity rather than "Otherness":

At the Gurdwara they slag Muslims off but when I meet customers at work, Muslim ones, and they talk to me in Punjabi, I just don't see it.

Perhaps the use of two mutually intelligible languages in non-religious contexts allows individuals to look beyond "the religious barrier" and to advance in a reconciliatory direction. Nonetheless, although a salient ethnic identity can be viewed as a positive factor in contexts like this, its relationship with religious identity can be a complex one.

\section{Ethnic pride versus religious identity}

Participants' accounts appeared to reveal the role of LLs as an immensely important self-aspect for the construction of their identities. However, there were some dissenting 
voices within the sample which highlighted dilemmas in the negotiation of religious and ethnic identities. Saba, for instance, constructed a narrative that illustrated the dilemmatic nature of her thinking:

Yeah, Arabic is important for us because it's the Prophet's language [...] I think Urdu is better than Mirpuri.

Within the context of religious practice, Saba appeared to prioritise and positively evaluate both Arabic and Urdu since these languages were viewed as more appropriate for the domain of religion. Given the centrality of religious identity among many British Pakistanis (Jacobson, 1997), it was not surprising that the LL was generally deemed to be "better" among Muslim participants. However, later in the interview, Saba appeared to contradict her previous statement:

Mirpuri is much clearer than Urdu anyway and it's easier to understand. I prefer that to Urdu [...] Yeah, it's a shame that 'apne' ['our people'] feel bad about using it more in public.

There was an understanding that the Prophet's language had been Arabic and that, as a good Muslim, one should acknowledge its alleged higher status. However, within the context of ethnicity, participants were less hesitant in expressing the perceived superiority of their vernaculars closely associated with their ethnic identities both in terms of the linguistic form ("much clearer") and general preference ("I prefer that to Urdu"). This also exemplifies participants' multiple (collective) identities and the salience of these identities in distinct contexts: in the context of religion, "us" referred to Muslims, whereas in the context of ethnicity, "apne" denoted the ethnolinguistic group.

While some accounts appeared to reflect participants' dilemmatic thinking in relation to their ethnic and religious identities, others appeared to categorise the functions of the languages associated with the aforementioned identities in a more systematic and coherent fashion. Amir's account, for instance, reflected a pragmatic approach to negotiating these identities:

We're from Gujarat so back home we speak Gujarati and we're proud of that. [...] Arabic is for the mosque and on Fridays.

For Amir, ethnic pride appears to take precedence over religious identity: he is proud of his HL and provides a justification for this pride ("we're from Gujarat"), while he appears to dismiss Arabic as a language reserved for a specific function, time and place. Both Arabic and Gujarati are acknowledged as forming part of the participant's linguistic repertoire and their respective functions are overtly stated. It is possible that Amir's account reflects his desire to distinguish himself from other Muslims in his geographic context:

It's annoying when you tell someone you're Muslim and they assume you're Pakistani. Well, no, I'm Gujarati and that's Indian.

Indeed, a majority of Muslims in the UK are of Pakistani descent (McLoughlin, 2006) which perhaps gives rise to the widespread assumption that Muslim identity is synonymous with Pakistani identity. Perhaps Amir's proud reiteration that his HL is Gujarati constitutes an attempt to maintain a sense of distinctiveness from other Muslims, who appear to be more inclined to prioritise their LL. His dismay at the loss of his distinctiveness in the eyes of individuals who assume he is Pakistani perhaps gives rise to a systematic organisation of his linguistic repertoire. For him, this repertoire is unproblematic: Gujarati is associated with his ethnicity and Arabic is reserved for religious purposes. 
Incompatibility of religious and ethno-linguistic identities

This largely unproblematic mode of negotiating one's religious and ethno-linguistic identities was by no means typical of the whole sample. Participants whose HL was considered a regional, non-standard variety lacking prestige generally reported having experienced difficulties, particularly within religious contexts, as a result of the perceived incompatibility of their religious identity and their affiliation to a given speech community. Kiren, who defined herself as a Punjabi-speaking Hindu, recounted her experiences in

a Hindu religious class dominated by Hindi-speakers:

In religious classes they'd basically laugh because we didn't speak Hindi at home so I'd just say stuff in Punjabi [...] You can understand obviously but it just made me out to be a bit of a gimp.

This account highlights an additional aspect of the relationship between religiolinguistic and ethno-linguistic identities. While the previous examples of negotiating these identities were largely intrapsychic, the present account focuses upon the intragroup (or perhaps intergroup) level of interaction. Despite the mutual intelligibility which Hindi and Punjabi afford their speakers, Kiren was reportedly mocked in her religious classes due to the fact that she used Punjabi, a language traditionally associated with Sikhism (Takhar, 2005). Tahir, an Urdu-speaking participant, also reported that:

When I hear Punjabi it basically reminds me of farmers and cows and stuff (laughs).

The connotations of Punjabi in a Hindu religious context are almost certainly inferior to the high status that the language holds in Sikh religious and Punjabi cultural contexts (Tomuletiu, 1997). Indeed, Kiren herself felt that her affiliation to the Punjabi speech community "made me out to be a bit of a gimp." This statement echoes Joseph's (2006) observation that religious and socio-political contexts govern language attitudes. Kiren expresses shame at having used her HL in this specific social context, although in others

Punjabi is my mother tongue and I wouldn't be me without it.

Her affiliation to an apparently incompatible speech community was sufficient to reduce her credibility as an authentic Hindu. Kiren appears to view her lack of access to the LL as a stimulus for others to repudiate her claim to group membership: "they'd basically laugh."

\section{Linguistic Otherness and religious alienation}

This section explores the dynamic relationship between language and religion and its social psychological consequences for collective religious identity.

\section{Language: a perceived barrier to religion}

Although the majority of participants claimed to be proficient speakers of their HL, there was a curious belief among participants that these languages had diverged from the LL, which had given rise to "barriers." For example, Veer said:

Their [the Sikh Gurus'] language was beautiful when they spoke it but like er now you've got slang in Punjabi [...] Sometimes I wonder if the Gurus can even understand our prayers.

At a religious level, Veer wonders whether his prayers in modern Punjabi would be received by the Sikh Gurus who had used a "beautiful" and pure form of Punjabi. 
This reflected the concern among some participants that their HL had deviated from the "original" LL. Similar concerns were expressed by other participants, although these statements did not reflect nostalgia but rather a sense of consequential indifference to religion:

I don't really know what they're on about in the Gurdwara so we're all a bit like 'Whatever you say' $[\ldots]$ We just go along because we've done it since we were kids and mum likes us to $[\ldots]$ - weddings and stuff like that really. (Daljit)

The perception of diachronic linguistic change also entails social psychological consequences. Due to the evolution of modern Punjabi and the preservation of older forms of Punjabi reserved for prayer and religious customs, participants such as Daljit reported a lack of identification with their religion. Daljit's account, in particular, suggests a sense of indifference, possibly because he is unable to understand the teachings and sermons, let alone critically evaluate them:

I just go along with whatever my mum says - bending down, bowing down.

Moreover, the fact that participants regularly attended the Sikh temple from early childhood perhaps led them to "just go along" out of habit. Indeed, both parental encouragement and the expectation of attendance at "weddings and stuff like that" were viewed as governing several participants' decisions to attend religious events:

We go [to the Gurdwara] at Vasakhi, weddings, births or whenever mum fancies going, mostly Sundays really (Pritika)

Perhaps due to the pervasive sense of "linguistic Otherness" among participants due to their lack of competence in the LL, many also reported feeling alienated from their religions. Similarly, Rosowsky (2006) notes that many young British Pakistanis are unable to understand Arabic sermons and that the religious commentary in Urdu is, in many cases, also beyond the understanding of these individuals. Thus, if their lack of competence in the LL(s) impedes active participation in the religion, it is perhaps understandable that many disidentify with it. For example, Baljit said:

I'm not the best Sikh really [...] I eat meat, drink alcohol, cut my hair. But I'd still describe myself as Sikh if someone asked me.

A possible result of this is that an individual may come to express religion in cultural rather than spiritual, terms. For the Sikh participants in this study, it would appear that religion comes to be viewed as alien primarily due to its expression in an esoteric and inaccessible language. This, however, does not inhibit their access to their place of worship or to religious events, which perhaps exemplifies participants' culturally based conceptualisation of religion.

\section{Departure from the religion - departure from the speech community}

In contrast to previous sections which have explored participants' lack of competence in the LL, this section considers a participant's reflections upon her language choice in ethnic and religious contexts. Bally, a Sikh participant, recounted her experiences of conversion to Islam at the request of her Muslim boyfriend. Although no longer a Muslim, Bally reflected upon her previous use of language:

He [my former boyfriend] wanted me to convert [to Islam] but my folks never accepted it [... ] My Punjabi became more like theirs [of Muslims] and I'd say 'Inshallah' at home and that ticked my parents off a lot. 
Bally reported having used English with her Muslim partner since both were Britishborn but, despite that, she assimilated her Punjabi to that of Muslims, thereby rendering her Punjabi "Muslim-sounding." Bally constructs herself as a passive recipient of this change: she says "my Punjabi became" rather than "I spoke." However, it is implied that her use of language was perhaps deliberate at times, since she would use terms specifically associated with Islam such as "Inshallah" with the knowledge that that "ticked my parents off a lot." This echoes observations elsewhere that apostasy and conversion to another religion can be viewed as a form of rebellion against one's parents and their values (Capolovitz \& Sherrow, 1977) and, in this particular case, this rebellion is most saliently materialised through her subversive use of Muslim Punjabi with her Sikh family.

Bally's account appears to express a strong reciprocal link between religious identity and language: her departure from her ascribed religion of Sikhism also entails her departure from the Sikh (Punjabi-speaking) community. In order to gain entry in her new religious community, her use of Punjabi had to change:

I used to be embarrassed about talking Punjabi to his mum because she told him [my former boyfriend] that we Sikhs have no manners and speak it badly.

On the other hand, her assimilation to the Muslim Punjabi speech community would inevitably offend her parents:

Anything that reminded them [my parents] of our relationship just hurt them.

In contexts in which religious differences are emphasised, even the most similar forms of language (such as Muslim Punjabi and Sikh Punjabi, with minimal lexical differences) can come to be viewed as completely alien linguistic systems. Such "linguistic Otherness" and "religious alienation" appear to have a mutual, reciprocal effect upon one another, each one reinforcing the other.

\section{Overview}

This study highlights some of the perceived functions of the LL in a variety of social contexts and identifies some of the psychosocial and linguistic difficulties which may arise from the construction of religious identity among young British-born SGAs and from their attempts to reconcile their religious and ethnic identities. One of the major credentials of this study lies in its identification of similar psychosocial strategies employed by participants from three distinct religions to manage their linguistic and identity complexity. The study has identified some of the commonalities and particularities in participants' experiences of language and religion and provides a detailed insight into the phenomenology of these experiences, although it is acknowledged that these results are not generalisable. Moreover, in contrast to the sociology of language and religion, which is interested primarily in the macro level of analysis, this study's social psychological perspective has allowed a glimpse of participants' psychological worlds both in terms of their individual and collective identities (Simon, 2004). More specifically, this study demonstrates the benefits of a qualitative approach to language and religious identity, since rich context-specific interpretations of participants' cognitions and attitudes towards language and religious and ethnic identities are provided.

One salient commonality in participants' accounts was the importance of religious identity in their psychological worlds, although both the degree of importance and their

own conceptualisation of these identities were by no means uniform. For instance, while some participants reported strong religious beliefs which appeared to underlie their 
religious attachment to the LL, others appeared to express religion as a cultural identity with the corresponding LL as an aspect of this identity. Nevertheless, language was frequently invoked as being a dominant self-aspect in the construction of their religious identities (Simon, 2004). It seemed that participants who reported being devoutly religious attached a great deal of religious importance to their LL often at the expense of their HL, which was frequently constructed as a linguistic deviation from the allegedly pure and homogeneous LL. Pargament and Mahoney (2005, p. 179) state that individuals may "go to great lengths to preserve and protect whatever they perceive to be sacred." Indeed, a majority of participants conceptualised their LL, or languages which they came to associate with their religious identities, as holy and thus as fundamental to their religious identities.

Pargament and Mahoney (2005, p. 180) also postulate that "the loss of the sacred can have devastating consequences." Indeed, the consequences of participants' disidentification with or lack of competence in the LL were considerable. Participants' consequential recourse to their HL or to languages which were not associated with their religions was often constructed as a barrier to a positive religious identity. This, in turn, gave rise to a number of intrapsychic reactions, including feelings of shame, ridicule and inferiority, and possibly identity threat due to attacks on the content dimension of their identities (Breakwell, 1986). Moreover, the inability to understand the LL appeared to engender feelings of indifference towards religion, since they were unable to understand the rationale underlying religious practice (see material under sub-section entitled "Language: a perceived barrier to religion"). Participants' accounts appeared to suggest a loss of agency in the construction of their religious views and beliefs which in turn encouraged a tendency to express religion as a cultural identity rather than as a personal belief system.

A central concern in the current investigation was individuals' cognitive and psychosocial management of their linguistic repertoires consisting of various languages. There was much ambivalence regarding the position of their HL relative to that of the LL. Some accounts indicated that the HL was inappropriate for use in religious contexts although in contexts in which ethnic or cultural identities might be more salient, this language was positively evaluated. Here a strand of sociolinguistic theory may be of use: Ferguson's (1959) model of diglossia postulates that a bilingual community reserves the "high" language for official, high-status contexts and the "low" language for informal contexts. Indeed, a majority of participants prioritised their religious identities over other identities, viewing the former as a high-status context worthy of the "high" language. Participants' attempts to make sense of this dichotomous situation seemed to induce feelings of confusion due to the highly context-dependent discrepancies in the social evaluation of these languages. For instance, Punjabi was positively evaluated as a Sikh LL but was viewed negatively as a Hindu LL, which could be problematic given that some individuals self-identified as "Hindu-Punjabi" and reported only knowing Punjabi and not Hindi. The close contextual analysis revealed that, in order to make sense of these complex situations, participants appeared to dichotomise both language use and language attitudes according to religion and ethnicity. Attention to how participants used language in their accounts was useful in the analysis of apparent inconsistencies in participants' talk; the LL was often constructed as a marker of religious identity whereas the HL was frequently constructed as taking precedence over the LL in contexts in which religion was not the salient self-aspect but rather ethnicity (Simon, 2004). 
In line with the argument that the LL holds a deep, religious meaning for individuals who prioritise their religious identities, participants also exhibited an awareness of the importance of the LL among other faith groups. Although some individuals refused to use the outgroup LL in inter-religious interaction, they often opted for more neutral forms of language which were not overtly associated with any particular religious group (e.g. use of the religiously unmarked greeting "hello ji" rather than the religious marked "asalaam alaikum"). This appeared to demonstrate an awareness of and respect for the distinctiveness of other religious groups, while safeguarding their own religious distinctiveness, an important identity principle (Breakwell, 1986). Furthermore, one participant provided a particularly positive account of how South Asians of different religious groups could collectively use their respective HL in non-religious contexts as a means of reconciling the religious ingroup and outgroups. This linguistic experience was viewed as leading to the deconstruction of myths and negative social representations prevalent in the group psyche. Participants generally concluded that South Asians of different faiths were in fact much more similar than they had previously believed themselves to be. This echoes the common ingroup identity model (Gaertner \& Dovidio, 2000; Gaertner, Dovidio, Anastasio, Bachman, \& Rust, 1993) which postulates that ingroup and outgroup categorisation can be shifted to a superordinate level which in turn encourages members of the two groups to see themselves as belonging to a common ingroup. Thus, a common language may be a possible self-aspect, or social psychological mechanism, which is capable of influencing this process of self and other categorisation. It perhaps emphasises the ethnic, racial and cultural similarities between members of these groups and downgrades the importance of religious difference.

Thus, in certain contexts, use of a given language can divide and delineate groups, whereas in others, it may stimulate feelings of similarity. The boundaries between LL and HL were constantly being negotiated by participants, both cognitively and discursively. For some Muslim participants, greater identification with Arabic as their LL, with this language being constructed as pure and homogeneous, and the systematic denial of the importance of HLs among Muslims perhaps afforded them a stronger sense of collective identity. This collective identity was seen as important, both numerically, encompassing Muslims from a variety of ethnic groups who share the same LL, and also ideologically, since this language was constructed as inherently superior to the HLs. However, the reality is that HL also forms part of SGAs' linguistic repertoires, which was frequently denied when religion was invoked. Breakwell's (1986) identity process theory identifies denial as a temporary intrapsychic strategy for coping with potentially threatening aspects of identity. This might also explain the fact that one participant sought to distance herself from Sikh Punjabi and to identify more with Muslim Punjabi since the former appeared to constitute a threat to self-interpretation in terms of a Muslim collective identity.

In general terms, it appears that both the LL and the HL were generally viewed by participants as playing an important role in their lives, although this was highly contextdependent. The analysis revealed that contexts in which religion was the salient self-aspect favoured the use of LL or languages viewed as being intrinsically related to the history of the religion. Indeed, these languages were generally constructed as being inherently superior to other languages. However, this was perhaps dependent upon participants' prior conceptualisation of a given language: if it was conceptualised as a LL, it appeared to hold a particular importance for many individuals, whereas its conceptualisation as a HL was often viewed as relatively less important. The analysis of participants' accounts demonstrated that factors appeared to underlie the sanctification of language and that 
religious ideology could endow any language with the characteristics necessary for it to be seen as "religious" or at least adequate for religious contexts. As Pandharipande (2006) states, media and popular representations play an influential role in the dissemination of such ideology.

Pervasive social representations of the LL as a fundamental aspect of religious identity may have negative psychosocial consequences for the religious identities of individuals lacking competence in the LL. More specifically, given the dominant perceptions of the sanctity of LL and of its importance in (religious) group identity, this lack of competence may have particularly negative outcomes for psychological wellbeing. For instance, participants who reported a lack of competence in their LL often positioned themselves or reported having been positioned by others as "Other" because the LL was perceived as being an inextricable component of religious identity. This could be tentatively interpreted in terms of a perceived lack of belonging, which has been linked to decreased self-esteem (Baumeister \& Leary, 1995). However, this study, as well as previous research (e.g. Rosowsky, 2006, 2007, 2008), indicates that many SGAs are not fully competent in the languages associated with their religious and even ethnic identities which might allow "complete" access to or claims upon these identities. Thus, on the one hand, individuals highlighted the importance of religious identity but, on the other, it was acknowledged that lack of proficiency in the LL could impede access to a strong religious identity. This could possibly give rise to a sense of dissonance resulting in potential threats to self-esteem and, thus, psychological well-being (Festinger, 1957). Indeed, individuals generally report greater subjective well-being when they view their behaviour and their identities as being consistent (Chirkov, Ryan, Kim, \& Kaplan, 2003). However, although it is argued that the LL seems to constitute an important aspect of participants' identities, the importance of the HL should not be downgraded since participants actively sought to reconcile their ethnic and religious identities. Indeed, the subjective perception of compatibility and coherence between one's multiple identities may be conducive to greater psychological well-being (Jaspal \& Cinnirella, 2009).

In conclusion, this study offers support to Rosowsky's (2006) call for an increased use of English in mosques and other religious institutions. It appears that the linguistic barrier to a positive religious identity exists across the three religious communities represented in this study. However, given the widespread perception of sanctity associated with the LL, a policy of "pretended bilingualism" may be an effective alternative to the sole use of the LL, which in many cases remains inaccessible to SGAs.

\section{References}

Bagguley, P., \& Hussain, Y. (2005). Flying the flag for England? Citizenship, religion and cultural identity among British Pakistani Muslims since September 11th and the "riots" of 2001. In T. Abbas (Ed.), Muslim Britain: Communities under pressure (pp. 208-221). London: Zed Books.

Baker, C. (2001). Foundations of bilingual education and bilingualism. New York: Multilingual Matters.

Baumeister, R.F., \& Leary, M.R. (1995). The need to belong: Desire for interpersonal attachments as a fundamental human motivation. Psychological Bulletin, 117(3), 497-529. 
Beit-Hallahmi, B., \& Argyle, M. (1997). The psychology of religious behaviour, belief and experience. London: Routledge.

Blunkett, D. (2002). Integration with diversity: Globalisation and the renewal of democracy and civil society. In M. Leonard, \& P. Griffith (Eds.), Reclaiming Britishness (pp. 65-77). London: The Foreign Policy Centre.

Brass, P.R. (2005). Language, religion and politics in North India. New Delhi: Sage.

Breakwell, G.M. (1986). Coping with threatened identities. London: Methuen.

Capolovitz, D., \& Sherrow, F. (1977). The religious drop-outs: Apostasy among college graduates. Beverly Hills, CA: Sage.

Carbonero, P. (2003). Estudios de Sociolingüística Andaluza. Sevilla: Secretariado de Publicaciones de la Universidad de Sevilla.

Chirkov, V., Ryan, R.M., Kim, Y., \& Kaplan, U. (2003). Differentiating autonomy from individualism and independence: A self-determination theory perspective on the internalization of cultural orientations and well-being. Journal of Personality and Social Psychology, 84, 97-109.

Dzialtuvaite, J. (2006). The role of religion in language choice and identity among Lithuanian immigrants in Scotland. In T. Omoniyi, \& J.A. Fishman (Eds.), Explorations in the sociology of language and religion (pp. 79-85). Amsterdam: John Benjamins.

Enneli, P., Modood, T., \& Bradley, H. (2005). Young Turks and Kurds: A set of "Invisible", disadvantaged groups. York: Joseph Rowntree Foundation.

Esposito, J. (2002). What everyone needs to know about Islam. Oxford: Oxford University Press.

Ferguson, C.A. (1959). Diglossia. Word, 15, 325-340.

Festinger, L. (1957). A theory of cognitive dissonance. Evanston, IL: Row Peterson.

Fishman, J.A. (1972). Language and nationalism: Two integrative essays. Rowley, UK: Newbury House.

Fishman, J.A. (1991). Reversing language shift. Clevedon, UK: Multilingual Matters.

Fishman, J.A. (1996). In praise of the beloved language: A comparative view of positive ethnolinguistic consciousness. Berlin: Mouton de Gruyter.

Fowler, J (1997). World religions. Eastbourne, UK: Sussex Academic Press.

Gaertner, S.L., \& Dovidio, J.F. (2000). Reducing intergroup bias: The common ingroup identity model. Philadelphia, USA: Psychology Press.

Gaertner, S.L., Dovidio, J.F., Anastasio, P.A., Bachman, B.A., \& Rust, M.C. (1993). The common ingroup identity model: Recategorization and the reduction of intergroup bias. In W. Stroebe, \& M. Hewstone (Eds.), European review of social psychology (Vol. 4, pp. 1-26). New York: John Wiley.

Gitelman, Z.Y., Kosmin, B.A., \& Kovacs, A. (2003). New Jewish identities: Contemporary Europe and beyond. Budapest: Central European University Press.

Gupta, A.F., \& Yeok, S.P (1995). Language shift in a Singapore family. Journal of Multilingual and Multicultural Development, 16(4), 301-314.

Harris, R. (2006). New ethnicities and language use. Basingstoke, UK: Palgrave Macmillan.

Hudson, R.A. (2001). Sociolinguistics. Cambridge: Cambridge University Press.

Hunsberger, B., \& Jackson, L. (2005). Religion, meaning, and prejudice. Journal of Social Issues, $61,807-826$.

Hymes, D. (1972). Models of the interaction of language and social life. In J. Gumperz, \& D. Hymes (Eds.), Directions in sociolinguistics: The ethnography of communication (pp. 35-71). New York: Holt, Rinehart and Winston.

Jacobson, J. (1997). Religion and ethnicity: Dual and alternative sources of identity among young British Pakistanis. Ethnic and Racial Studies, 20, 238-256.

Jaspal, R., \& Cinnirella, M. (2009). Coping with potentially incompatible identities: Accounts of religious, ethnic and sexual identities from British Pakistani men who identify as Muslim and gay. Manuscript submitted for publication.

Joseph, J.E. (2006). The shifting role of languages in Lebanese Christian and Muslim identities. In T. Omoniyi, \& J.A. Fishman (Eds.), Explorations in the sociology of language and religion (pp. 165-179). Amsterdam: John Benjamins. 
Kalra, J.S., Purewal, N.K., \& Ward, S. (2001). Punjabi. Lincolnwood, IL: NTC/ Contemporary Publishing Company.

McGrath, A.E. (2002). The future of Christianity. Oxford: Blackwell.

McLoughlin, S. (2006). Writing a BrAsian city: "Race," culture and religion in accounts of postcolonial Bradford. In N. Ali, V.S. Kalra, \& S. Sayyid (Eds.), A postcolonial people: South Asians in Britain (pp. 110-140). London: Hurst.

Miller, L., \& Kelley, B.S. (2005). Relationships of religiosity and spirituality with mental health and psychopathology. In R.F. Paloutzian, \& C.L. Park (Eds.), Handbook of the psychology of religion and spirituality (pp. 460-478). New York: Guilford Press.

Omoniyi, T., \& Fishman, J.A. (2006). Introduction. In T. Omoniyi, \& J.A. Fishman (Eds.), Explorations in the sociology of language and religion (pp. 1-9). Amsterdam: John Benjamins.

Pandharipande, R.V. (2001). The role of language of religion in the convergence of South Asian languages. In R. Singh (Ed.), The yearbook of South Asian languages and linguistics (pp. 289-310). New Delhi: Sage.

Pandharipande, R.V. (2006). Ideology, authority and language choice: Language of religion in South Asia. In T. Omoniyi, \& J.A. Fishman (Eds.), Explorations in the sociology of language and religion (pp. 141-164). Amsterdam: John Benjamins.

Pargament, K.I. (1997). The psychology of religion and coping. New York: Guilford Press.

Pargament, K.I., \& Mahoney, A. (2005). Sacred matters: Sanctification as a vital topic for the psychology of religion. International Journal for the Psychology of Religion, 15, 179-198.

Pickthall, M.M. (1997). The meaning of the glorious Koran. New York: Plume.

Robson, J. (1971). Hadith. In B. Lewis, V.L. Menage, C. Pellat, \& J. Schacht (Eds.), The encyclopaedia of Islam (pp. 23-29). New York: Macmillan.

Roccas, S., \& Brewer, M.B. (2002). Social identity complexity. Personality and Social Psychology Review, 6, 88-106.

Rosowsky, A. (2006). The role of liturgical literacy in UK Muslim communities. In T. Omoniyi, \& J.A. Fishman (Eds.), Explorations in the sociology of language and religion (pp. 309-324). Amsterdam: John Benjamins.

Rosowsky, A. (2007). Qur'anic literacy: Its central role in the life of UK Muslim communities. NALDIC Quarterly, 5(2), 44.

Rosowsky, A. (2008). Muslim, English, or Pakistani? Multilingual identities in minority ethnoreligious communities. In P. Martinez, D. Moore, \& V. Spaëth (Eds.), Plurilinguismes et Enseignement (pp. 127-140). Paris: Riveneuve.

Samuels, J. (1995). Multilingualism in the emerging educational dispensation. In Proceedings of South African Applied Linguistics Association (SAALA) 15. Stellenbosch: University of Stellenbosch.

Shankar, G. (2003). Imagining India(ns): Cultural performances and diaspora politics in Jamaica. Unpublished $\mathrm{PhD}$. dissertation, University of Texas.

Simon, B. (2004). Identity in modern society: A social psychological perspective. Oxford: Blackwell. Singh, K (2005). A history of the Sikhs. Oxford: Oxford University Press.

Singh, R., Dasgupta, P., \& Lele, J.K. (1995). Explorations in Indian sociolinguistics. New Delhi: Sage.

Smith, J.A. (1996). Beyond the divide between cognition and discourse: Using interpretative phenomenological analysis in health psychology. Psychology and Health, 11, 261-271.

Smith, J.A., Harré, R., \& van Langenhove, L. (1995). Idiography and the case-study. In J.A. Smith, R. Harré, \& L . van Langenhove (Eds.), Rethinking psychology (pp. 59-69). London: Sage.

Smith, J.A., \& Osborn, M. (2008). Interpretative phenomenological analysis. In J.A. Smith (Ed.), Qualitative psychology: A practical guide to methods (2nd ed., pp. 53-80). London: Sage.

Takhar, O.K. (2005). Sikh identity: An exploration of groups among Sikhs. Aldershot: Ashgate.

Tomuletiu, S. (1997). Language loyalty and group identity in the South Asian community in Britain. Studia Europaea, 1(2), 15-22.

Verkuyten, M. (2005). The social psychology of ethnic identity. London: Psychology Press.

Ward, K. (2000). Religion and community. Oxford: Clarendon Press. 
Waugh, E. (1977). Muharram rites: Community death and rebirth. Religious encounters with death. In F.E. Reynolds, \& E.H. Waugh (Eds.), Insights from the history and anthropology of religions (pp. 200-213). University Park, PA: The Pennsylvania State University Press.

Webber, J. (1997). Jews and Judaism in contemporary Europe: Religious or ethnic group? Ethnic and Racial Studies, 20, 225-252.

Wei, L. (2000). The bilingualism reader. London: Routledge.

Willig, C. (2007). Reflections on the use of a phenomenological method. Qualitative Research in Psychology, 4, 209-225.

Wolf, H. (2001). English in Cameroon. Berlin: Mouton de Gruyter. 